\title{
Managing In The Global Economy: An Integrative Concept For A Cross-Functional MBA Cornerstone Course
}

\author{
Alfred Mettler, (Email: mettler@gsu.edu), Georgia State University, Atlanta
}

\begin{abstract}
This paper documents how faculty from different departments at Georgia State University's Robinson College of Business developed, implemented and successfully delivered a crossfunctional cornerstone core MBA course. The course provides an introduction to fundamental business concepts from a global managerial perspective and is based on an integrative framework that especially emphasizes the relationships, connections and dependencies among functional areas in different industry life-cycle situations. The course has to be taken by all entering MBA students and has been introduced in Fall 2004. Since its first semester of delivery it has received top evaluations from the students and is one of the most popular classes in the College. What was initially considered to be an "impossible thing", turned out to be a huge success.
\end{abstract}

\section{INTRODUCTION}

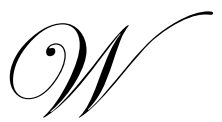

hat would you do if you had one week of vacation time in a country you have never visited before, let's say in Italy? Most likely you would want to visit some of the famous cities there, maybe spend 2 days in Rome, a day in Florence, a day in Venice, and maybe also enjoy a few days in a nice place at one of the Mediterranean beaches. Would you, after such a one-week vacation, know more about Italy than before? The answer is probably yes. Would you have learnt some Italian words, met Italian people, seen parts of another culture? Most likely. Would you feel enriched because you had a chance to visit and interact with another part of the world? Hopefully!

What would you do if you had a chance to revisit Italy, this time for four weeks instead of one week of vacation time? You would probably stay for an extended time in several cities, visit other parts of the country like Tuscany, the northern Alpine region, or Sicily. Maybe you would also take a trip to one of the islands, like Sardinia or Capri; maybe you would even consider taking a language-course or a cooking class. After four weeks of vacationing there, would you know much more about the country compared to the one-week stay? Most likely yes. Would you have a deeper knowledge of the people, language, and culture of Italy than after the previous one-week stay? Hopefully. Would you already be a specialist in Italian language and culture after the four weeks? Well, let's face it, most likely not yet, but the stay would perfectly prepare you for another, this time much longer stay in the country so that you could really deepen your knowledge further.

So let's assume you will go back to Italy very soon after your 4-week stay, this time for a full year. In this case you would move somewhere there, get familiar with the day-to-day life of your city or town, maybe get a job, you would travel around, sit in coffee shops, read the newspapers, in short: You would be deeply immersed in the Italian culture and life-style. And of course, after such a stay you would know a lot about the country and would probably consider yourself an Italy-specialist, and rightly so.

What has all this to do with an MBA program? Well, this is exactly one of the ways in which we look at it, and especially how we think about our cross-functional cornerstone MBA course titled "Managing in the Global Economy”. Learning about business is for an entering MBA student, so do we think, similar to discovering another country. Most of the students already know something about business, so in our example it is like if they had already 
spent a one-week vacation in Italy. However, in order to be come "Italy-specialists" they have now to familiarize themselves in a much deeper way with the language, culture, social context, geography, human behavior, traditions, "best practices", foreign relations, etc. So if the whole MBA program corresponds to the one year stay in Italy, then our "Managing in the Global Economy class is comparable to the preceding four week visit.

The rest of the paper is organized as follows: We first describe the context in which the idea of this course came up, how the detailed concept was developed, and how it was integrated into the MBA program. We then document how the class has been delivered during 3 subsequent semesters, i.e. over the course of a full academic year. Finally we discuss the key aspects that were in our opinion necessary for making the course a success.

\section{THE CREATION OF THE COURSE}

The roots of this course go back to the summer of 2002, when a newly appointed Associate Dean for Masters Programs was charged with - among other things - an evaluation and possible restructuring of GSU's existing parttime MBA program. In the past the college had gone through several unsuccessful attempts of redesigning the MBA curriculum, so at first there was quite some skepticism about if/how to tackle this issue again. The way the new Associate Dean approached it was to form a "MBA Steering Committee" (MBASC), consisting of 12 faculty members from 6 different departments (two of each of the following departments: Accounting, CIS, Finance, Managerial Sciences, Marketing, Risk Management \& Insurance).

Over the course of the next 9 months the MBASC met regularly (usually weekly for two hours) and developed a proposal for a redesigned MBA program which was highly integrative and global in orientation, and whose main innovations fell into three categories: (1) new courses, (2) new packaging, and (3) new levels of consistency, integration, and internationalization across the program. One of the new courses mentioned in (1) above was a holistic overview of business concepts, titled "MBA 8000 - Managing in the Global Economy". The MBASC had come to believe that a thrilling course in how businesses grow, change, and die and how they function during these stages would establish a baseline of interdisciplinary knowledge that would not only be enormously valuable in its own right, but would also enhance students' performance in the rest of the program. The course, mandatory for all entering MBA students, would have touchstones for all of the core business disciplines, but would combine these in such a way that students should see business processes holistically rather than as silos.

In July 2003 the MBASC's proposal was reviewed and approved by the college's Executive Committee. During the Fall semester of 2003 several meetings were held to inform the college faculty about the proposed redesigned program and its main innovations. In January 2004, a college faculty meeting unanimously approved the proposal and decided that it should come into effect at the beginning of Fall semester 2004. This meant that within the next 6 months a team of instructors would have to develop the syllabus and contents of the new Managing in the Global Economy class. Based on the MBASC proposal, the course concepts were organized along two dimensions of a $4 \mathrm{x} 5$ matrix as follows (see also table 1 below):

- $\quad$ The organizational life cycles, A-D, (start-up and initial growth, fighting for pole positions, competing in mature markets, renewal in declining industries;

- $\quad$ Key business activities, 1-5, (identifying markets, industries and competitive advantages; finding and retaining customers; organizing and using cash and capital; integrating systems into organizations; developing relationships among managers and employees). 
TABLE 1: MANAGING IN THE GLOBAL ECONOMY - COURSE MATRIX

\begin{tabular}{|c|c|c|c|c|}
\hline & $\begin{array}{l}\text { Start-Up And } \\
\text { Initial Growth (A) }\end{array}$ & $\begin{array}{l}\text { Fighting For Pole } \\
\text { Positions (B) } \\
\end{array}$ & $\begin{array}{l}\text { Competing In } \\
\text { Mature Markets (C) }\end{array}$ & $\begin{array}{l}\text { Renewal In Declining } \\
\text { Industries (D) }\end{array}$ \\
\hline $\begin{array}{l}\text { Identifying } \\
\text { markets, in- } \\
\text { dustries and com- } \\
\text { petitive } \\
\text { advantages } \\
\text { (1) } \\
\end{array}$ & $\begin{array}{l}\text { A } \\
\text { Concepts } \\
\text { (Examples) } \\
\text { General Learning } \\
\text { Objectives } \\
\text { Selected Material } \\
\end{array}$ & $\begin{array}{l}\text { 1B } \\
\text { Concepts (Examples) } \\
\text { General Learning } \\
\text { Objectives } \\
\text { Selected Material }\end{array}$ & $\begin{array}{l}1 \mathrm{C} \\
\text { Concepts (Examples) } \\
\text { General Learning } \\
\text { Objectives } \\
\text { Selected Material }\end{array}$ & $\begin{array}{l}\text { 1D } \\
\text { Concepts (Examples) } \\
\text { General Learning } \\
\text { Objectives } \\
\text { Selected Material }\end{array}$ \\
\hline $\begin{array}{l}\text { Finding and } \\
\text { retaining } \\
\text { customers } \\
\text { (2) }\end{array}$ & $\begin{array}{l}\text { 2A } \\
\text { Concepts } \\
\text { (Examples) } \\
\text { General Learning } \\
\text { Objectives } \\
\text { Selected Material } \\
\end{array}$ & $\begin{array}{l}\text { 2B } \\
\text { Concepts (Examples) } \\
\text { General Learning } \\
\text { Objectives } \\
\text { Selected Material }\end{array}$ & $\begin{array}{l}\text { 2C } \\
\text { Concepts (Examples) } \\
\text { General Learning } \\
\text { Objectives } \\
\text { Selected Material }\end{array}$ & $\begin{array}{l}\text { 2D } \\
\text { Concepts (Examples) } \\
\text { General Learning } \\
\text { Objectives } \\
\text { Selected Material }\end{array}$ \\
\hline $\begin{array}{l}\text { Organizing and } \\
\text { using cash and } \\
\text { capital } \\
\text { (3) }\end{array}$ & $\begin{array}{l}\text { 3A } \\
\text { Concepts } \\
\text { (Examples) } \\
\text { General Learning } \\
\text { Objectives } \\
\text { Selected Material } \\
\end{array}$ & $\begin{array}{l}\text { 3B } \\
\text { Concepts (Examples) } \\
\text { General Learning } \\
\text { Objectives } \\
\text { Selected Material }\end{array}$ & $\begin{array}{l}\text { 3C } \\
\text { Concepts (Examples) } \\
\text { General Learning } \\
\text { Objectives } \\
\text { Selected Material }\end{array}$ & $\begin{array}{l}\text { 3D } \\
\text { Concepts (Examples) } \\
\text { General Learning } \\
\text { Objectives } \\
\text { Selected Material }\end{array}$ \\
\hline $\begin{array}{l}\text { Integrating } \\
\text { systems into } \\
\text { organizations } \\
\text { (4) }\end{array}$ & $\begin{array}{l}\text { 4A } \\
\text { Concepts } \\
\text { (Examples) } \\
\text { General Learning } \\
\text { Objectives } \\
\text { Selected Material }\end{array}$ & $\begin{array}{l}\text { 4B } \\
\text { Concepts (Examples) } \\
\text { General Learning } \\
\text { Objectives } \\
\text { Selected Material }\end{array}$ & $\begin{array}{l}\text { 4C } \\
\text { Concepts (Examples) } \\
\text { General Learning } \\
\text { Objectives } \\
\text { Selected Material }\end{array}$ & $\begin{array}{l}\text { 4D } \\
\text { Concepts (Examples) } \\
\text { General Learning } \\
\text { Objectives } \\
\text { Selected Material }\end{array}$ \\
\hline $\begin{array}{l}\text { Developing } \\
\text { relationships } \\
\text { among managers } \\
\text { and employees } \\
\text { (5) }\end{array}$ & $\begin{array}{l}\text { 5A } \\
\text { Concepts } \\
\text { (Examples) } \\
\text { General Learning } \\
\text { Objectives } \\
\text { Selected Material } \\
\end{array}$ & $\begin{array}{l}\text { 5B } \\
\text { Concepts (Examples) } \\
\text { General Learning } \\
\text { Objectives } \\
\text { Selected Material }\end{array}$ & $\begin{array}{l}5 \mathrm{C} \\
\text { Concepts (Examples) } \\
\text { General Learning } \\
\text { Objectives } \\
\text { Selected Material }\end{array}$ & $\begin{array}{l}\text { 5D } \\
\text { Concepts (Examples) } \\
\text { General Learning } \\
\text { Objectives } \\
\text { Selected Material }\end{array}$ \\
\hline
\end{tabular}

The MBASC's proposal furthermore suggested that:

- 12 out of the 15 class sessions of a semester should be devoted to the coverage of the course material (the remaining 3 class sessions were reserved for Mid Term Exam, Final Exam, and an external speaker session);

- $\quad$ In each of the 12 weeks a different cell of the matrix should be the key topic to be covered;

- $\quad$ Over the course of a semester the course should cover at least one cell from each life cycle stage (1-5) and one cell from each business activity (A-D);

- While there would be some flexibility for the individual course instructors in terms of putting more emphasis on specific life cycle stages or business activities than on others, all sections should cover the 20 cells of the course content matrix either directly or by association;

- At least 4 out of the 12 sessions devoted to the coverage of the material should address international/global issues, either via cases or via specific relevant concepts;

- $\quad$ The course should draw content from multiple sources, including relevant current business press articles, selected textbook chapters, case studies, etc.;

- $\quad$ Class size should be limited to 40 students.

After having taken this course, students should be able to identify, describe and discuss different stages of the organizational life cycle as well as different key business activities from a global standpoint. Furthermore the students should be able to apply selected management tools to solve problems a firm typically faces in different life cycle stages and for different business activities (see table 2): 
TABLE 2: MANAGING IN THE GLOBAL ECONOMY - GENERAL LEARNING OBJECTIVES

\begin{tabular}{|c|c|c|c|c|}
\hline & $\begin{array}{l}\text { Start-Up And Initial } \\
\text { Growth (A) }\end{array}$ & $\begin{array}{l}\text { Fighting For Pole } \\
\text { Positions (B) }\end{array}$ & $\begin{array}{l}\text { Competing In } \\
\text { Mature Markets (C) }\end{array}$ & $\begin{array}{l}\text { Renewal In } \\
\text { Declining Industries } \\
\text { (D) }\end{array}$ \\
\hline $\begin{array}{l}\text { Identifying markets, } \\
\text { industries and } \\
\text { competitive } \\
\text { advantages } \\
\text { (1) } \\
\end{array}$ & \multirow{5}{*}{\multicolumn{4}{|c|}{$\begin{array}{l}\text { 1. Identify, describe, and discuss firms in: } \\
\text { a. the initial stage of the firm lifecycle, } \\
\text { b. the pole stage of the firm lifecycle, } \\
\text { c. the mature stage of the firm lifecycle, and } \\
\text { d. the renewal/dying stage of the firm lifecycle. } \\
\text { 2. Apply tools to solve problems relating to firms in: } \\
\text { a. the initial stage of the firm lifecycle, } \\
\text { b. the pole stage of the firm lifecycle, } \\
\text { c. the mature stage of the firm lifecycle, and } \\
\text { d. the renewal/dying stage of the firm lifecycle. }\end{array}$}} \\
\hline $\begin{array}{l}\text { Finding and retaining } \\
\text { customers } \\
\text { (2) }\end{array}$ & & & & \\
\hline $\begin{array}{l}\text { Organizing and using } \\
\text { cash and capital } \\
\text { (3) }\end{array}$ & & & & \\
\hline $\begin{array}{l}\text { Integrating systems } \\
\text { into organizations } \\
\text { (4) }\end{array}$ & & & & \\
\hline $\begin{array}{l}\text { Developing } \\
\text { relationships among } \\
\text { managers and } \\
\text { employees } \\
\text { (5) }\end{array}$ & & & & \\
\hline
\end{tabular}

Also, the MBASC emphasized in its proposal that the course was designed as the mandatory cornerstone course for all new MBA students. Faculty who would teach this course would have to work closely together in developing the curriculum and the detailed syllabus for each semester. It was evident that the nature of the course would require quite some coordination with a special emphasis on teaching/delivery.

Immediately after the approval of the revised MBA program (and therefore after the approval of the new cornerstone course) the Associate Dean for Masters Programs appointed a member of the MBASC as the course coordinator and charged him with leading the efforts to develop the details of the class.

\section{COURSE CONTENT AND COURSE INSTRUCTORS}

Over the next several months the newly appointed course coordinator started to collect possible course material and to talk to faculty who were interested in teaching the course. Since the MBASC's member came from different departments within the college, there had always been significant support for this class, and with input from various faculty members a first course content matrix was developed. It showed possible concepts for each of the 20 cells, 1A to 5D (see table 3 below). This course content matrix was not meant to be binding; it should just serve as a starting point for the development of the syllabus for the class. Also, the global aspects of the course were not explicitly mentioned in the content matrix, but it was clear that the team of instructors would have to find a way to integrate them. With respect to structure and content, this was the final input from the MBASC to the course; the exact details would now have to be developed and decided by the team of instructors.

The next step was to find faculty members who were willing to teach this class. There was still quite some skepticism whether such a class could really be successfully delivered, and it was clear that there would be a significant upfront investment in terms of time commitment for the preparation of the individual class sessions. The 
course coordinator was convinced that the team of instructors should ideally consist of 6-8 full-time faculty members from as many different departments as possible. No department should ever "own" the course; hence it should remain under direct control of the MBASC and the Associate Dean for Masters Programs.

Also, in order to have a maximum of credibility within the college, it was important to have faculty members of different academic ranks. Under all circumstances it should be avoided that the course would ever be regarded as "being taught by adjunct faculty" or "being taught by rookies". In the course coordinator's opinion the ideal MBA 8000 faculty would consist of enthusiastic teachers with a proven classroom performance record and with a genuine interest in global businesses.

In May 2004 a team of four initial MBA 8000 instructors had been formed. The four instructors had the following academic ranks and department affiliations:

- $\quad$ Assistant Professor, Department of Finance (course coordinator)

- $\quad$ Associate Professor, Department of Managerial Sciences

- $\quad$ Associate Professor, Department of Managerial Sciences

- $\quad$ Full-time instructor, Department of Marketing

Each of the instructors had been with GSU for at least seven years, two out of the four instructors were members of the MBASC and had therefore participated in the development of the class from the very beginning.

\section{THE FIRST ROUND OF THE COURSE: FALL 2004}

During Summer 2004 the four instructors met regularly and discussed possible course content in more details. Textbooks were reviewed, cases were analyzed, and newspaper-databases were researched, all with the focus on finding suitable material for the course.

Very soon it became clear that the course could not follow a traditional textbook approach, but would instead have to be based on cases and real world examples. Also, based on an input from one of the team members, it seemed like Thomas Friedman's classic book on Globalization, "The Lexus and the Olive Tree” would be perfectly suited as a basis for the discussion of global issues. Finally, the instructors wanted as much of the course content as possible to be accessible online. Based on these findings the team decided that the required course material would consist of the following items:

- $\quad$ A collection of cases and readings that could be downloaded by the students from the following website: http://www.study.net

- $\quad$ A subscription to the Economist and the Wall Street Journal for the duration of the semester

- $\quad$ Thomas Friedman's book "The Lexus and the Olive Tree” (paperback version)

The next step was to decide about the cases and readings that should be used. The approach of the instructor team was that each of the instructors suggested possible cases/readings from his/her field, presented it to the group, and showed a possible teaching plan. If the group agreed, the case/reading was included in the syllabus. Since there were areas where none of the four instructors had significant experience (for example IT-aspects), they decided to rely in these cases on faculty colleagues who had the required expertise and therefore actively solicited their input. The process of putting the final course content together was intensive and put the instructor team on a steep learning curve.

Two weeks before the Fall semester 2004 started, the syllabus as well as the www.study.net course website were ready and the students who were enrolled in the class were informed about it via e-mail (table 4 shows the detailed content of the individual class sessions). For the Fall 2004 semester six sections of MBA 8000 were being offered and more than 180 students had enrolled in the course; therefore the average class size was about 30 students. 
TABLE 3: MANAGING IN THE GLOBAL ECONOMY - POSSIBLE COURSE CONTENT MATRIX

\begin{tabular}{|c|c|c|c|c|}
\hline & $\begin{array}{l}\text { Start-up and initial } \\
\text { growth (A) }\end{array}$ & $\begin{array}{l}\text { Fighting for pole } \\
\text { positions (B) }\end{array}$ & $\begin{array}{l}\text { Competing in mature } \\
\text { markets }(C)\end{array}$ & $\begin{array}{l}\text { Renewal in declining } \\
\text { industries (D) }\end{array}$ \\
\hline $\begin{array}{l}\text { Identifying } \\
\text { markets, } \\
\text { industries } \\
\text { and } \\
\text { competitive } \\
\text { advantages } \\
\text { (1) }\end{array}$ & $\begin{array}{ll}\text { 1A Concepts } \\
\text { - } & \text { Fragmented industry } \\
\text { structure } \\
\text { - } & \text { Estimating demand, } \\
\text { new product } \\
\text { development } \\
\text { - } \quad \text { Entrepreneurship } \\
\text { - } \quad \text { Fastest growing } \\
\text { companies and } \\
\text { industries } \\
\text { - } \begin{array}{l}\text { Porter-model with } \\
\text { extensions }\end{array}\end{array}$ & $\begin{array}{l}\text { 1B Concepts } \\
\text { - Barriers to entry, } \\
\text { existing and under } \\
\text { construction } \\
\text { - Appropriation of rents } \\
\text { - Development of } \\
\text { resources and } \\
\text { capabilities to gain } \\
\text { competitive advantage. } \\
\text { - Strategic information } \\
\text { systems }\end{array}$ & $\begin{array}{l}\text { 1C Concepts } \\
\text { - Rivalry among firms } \\
\text { - Appropriation of rents in } \\
\text { cost-based competition } \\
\text { - Sustaining established } \\
\text { capabilities and } \\
\text { competitive advantages } \\
\text { - Bricks and mortar } \\
\text { strategies for } \\
\text { supplemented } \\
\text { intermediaries } \\
\text { - Outsourcing activities }\end{array}$ & $\begin{array}{l}\text { 1D Concepts } \\
\text { - Five forces of } \\
\text { competition } \\
\text { - Moving to a Focus- } \\
\text { oriented strategy } \\
\text { - Returning from } \\
\text { bankruptcy } \\
\text { - Turnaround strategies }\end{array}$ \\
\hline $\begin{array}{l}\text { Finding and } \\
\text { retaining } \\
\text { customers } \\
(2)\end{array}$ & $\begin{array}{l}\text { 2A Concepts } \\
\text { - Developing customer } \\
\text { databases } \\
\text { - Buyer behavior } \\
\text { - Product life cycles } \\
\text { - Marketing mix (4 P's) } \\
\text { - Relationship marketing }\end{array}$ & $\begin{array}{l}\text { 2B Concepts } \\
\text { - Brand management with } \\
\text { the } 4 \text { P's } \\
\text { - Market segmentation } \\
\text { - Customer life-time } \\
\text { value }\end{array}$ & $\begin{array}{l}\text { 2C Concepts } \\
\text { - Marketing mix in mature } \\
\text { markets } \\
\text { - Commoditization } \\
\text { - Price competition } \\
\text { - Customer relationships in } \\
\text { mature markets }\end{array}$ & $\begin{array}{l}\text { 2D Concepts } \\
\text { - } \quad \text { The } 4 \text { P's and business } \\
\text { renewal } \\
\text { - Maximizing profits in } \\
\text { declining } \\
\text { products/services } \\
\text { - Marketing efficiently } \\
\text { - Value of loyal } \\
\text { - customers } \\
\text { Renewing } \\
\text { product/service life- } \\
\text { cycles }\end{array}$ \\
\hline $\begin{array}{l}\text { Organizing } \\
\text { and using } \\
\text { cash and } \\
\text { capital } \\
\text { (3) }\end{array}$ & $\begin{array}{l}\text { 3A Concepts } \\
\text { - The meaning of growth } \\
\text { and how it is financed } \\
\text { - Angel financing, } \\
\text { venture capital and } \\
\text { private equity, IPO’s } \\
\text { - Financial statements/ } \\
\text { financial planning } \\
\text { - Meaning of risk and } \\
\text { return }\end{array}$ & $\begin{array}{l}\text { 3B Concepts } \\
\text { - } \text { Mergers and } \\
\text { acquisitions } \\
\text { - } \text { Financial implications } \\
\text { of cooperative } \\
\text { relationships } \\
\text { - Financing with equity } \\
\text { and debt } \\
\text { - Conflicts between } \\
\text { shareholders and } \\
\text { - } \text { stakeholders } \\
\text { Measuring success } \\
\end{array}$ & $\begin{array}{l}\text { 3C Concepts } \\
\text { - Aspects of financial } \\
\text { engineering } \\
\text { - Tax aspects } \\
\text { - Impact of diversification } \\
\text { - Shareholder vs. } \\
\text { stakeholder wealth } \\
\text { maximization }\end{array}$ & $\begin{array}{l}\text { 3D Concepts } \\
\text { - Bankruptcy and } \\
\text { liquidation } \\
\text { - Divestitures } \\
\text { - Bad loans / workout } \\
\text { - Going private }\end{array}$ \\
\hline $\begin{array}{l}\text { Integrating } \\
\text { systems into } \\
\text { organizations } \\
\text { (4) }\end{array}$ & $\begin{array}{l}\text { 4A Concepts } \\
\text { - General systems theory } \\
\text { - Business models and } \\
\text { strategic planning } \\
\text { - Virtual organizational } \\
\text { designs } \\
\text { - Atomic business models } \\
\text { for e-commerce } \\
\text { - Organic views of } \\
\text { organizations }\end{array}$ & $\begin{array}{l}\text { 4B Concepts } \\
\text { - Managing the supply } \\
\text { chain/supply network } \\
\text { - Intrafirm and interfirm } \\
\text { management and control } \\
\text { systems } \\
\text { - Formality-flexibility } \\
\text { challenges } \\
\text { - Synthesizing systems in } \\
\text { M\&A }\end{array}$ & $\begin{array}{l}\text { 4C Concepts } \\
\text { - Enterprise resource } \\
\text { planning systems } \\
\text { - B2B systems } \\
\text { - Decision support systems } \\
\text { and EDI }\end{array}$ & $\begin{array}{l}\text { 4D Concepts } \\
\text { - Reengineering systems } \\
\text { - Enterprise-wide systems } \\
\text { - Integration failures }\end{array}$ \\
\hline $\begin{array}{l}\text { Developing } \\
\text { relationships } \\
\text { among } \\
\text { managers } \\
\text { and } \\
\text { employees } \\
\text { (5) }\end{array}$ & $\begin{array}{l}\text { 5A Concepts } \\
\text { - Reconciling the interests } \\
\text { of entrepreneurs and } \\
\text { their firms } \\
\text { - Designing simple } \\
\text { structures for small } \\
\text { firms }\end{array}$ & $\begin{array}{l}\text { 5B Concepts } \\
\text { - Resource dependencies } \\
\text { of firms } \\
\text { - Aligning power with } \\
\text { responsibility } \\
\text { - Systems and structures } \\
\text { to facilitate } \\
\text { organizational growth } \\
\text { - Management } \\
\text { compensation } \\
\end{array}$ & $\begin{array}{l}\text { 5C Concepts } \\
\text { - Division of authority in } \\
\text { mature firms } \\
\text { - Agency issues of } \\
\text { owners vs. managers } \\
\text { - Avoiding rigidity in } \\
\text { larger organizations }\end{array}$ & $\begin{array}{l}\text { 5D Concepts } \\
\text { - Retaining key people in } \\
\text { struggling firms } \\
\text { - De-layering, re- } \\
\text { engineering, and } \\
\text { downsizing }\end{array}$ \\
\hline
\end{tabular}


The fine-tuning of the class occurred during the course of the semester, when the four instructors met every week for 2 hours. During these meetings the team usually first de-briefed the preceding class, analyzing what went well and what could be improved for the next semester. Then they extensively discussed the content of the next class and decided about the additional reading material from the Economist and the WSJ. Whenever possible, there was at least one article from the Economist and one article from the Wall Street Journal that accompanied the case/readings for a specific week. Also, the team developed a limited number of ppt-slides that could be used in class for each week. As an example, exhibit 1 shows the first ppt-slide for weeks 2 and 3, containing the cases, readings, and also the corresponding articles from the WSJ and the Economist.

The way that the global context was integrated in the class was first of all via "The Lexus and the Olive Tree”. The book provides a very accessible and highly interesting framework of the Globalization process and uses countless business situations as examples. Also, several cases were international in nature (especially the ones used in weeks $4,510,11,12$ ), and many of the WSJ/Economist articles dealt with global issues. The crucial point was to build the bridges between the individual weeks by making a lot of cross-references and by integrating the cases/readings/articles into the framework of Friedman's book. This was of course something, which in the very end the instructors were individually responsible for.

Special attention had to be given to the question of how to evaluate the students. The instructor team decided that a significant part of the course grade should be based on participation, corresponding to the case-oriented structure of the class. Also, the exams should be instructor-specific, i.e. there was no common mid term or common final exam. The grade weights were stated in the syllabus as follows:

$\begin{array}{ll}\text { Final Exam } & 35 \% \\ \text { Mid Term Exam } & 25 \% \\ \text { Contribution to class } & 30 \% \\ \text { Instructor-Specific Component } & 10 \%\end{array}$

Mid term and final exams required written answers to questions about the material and asked students to use the skills developed in the class to analyze a given business situation. They were either in-class exams or take home exams.

A student's contribution to class was assessed in terms of the quality and quantity of his/her participation in the discussion of the assigned cases and readings. Aspects to be considered were for example:

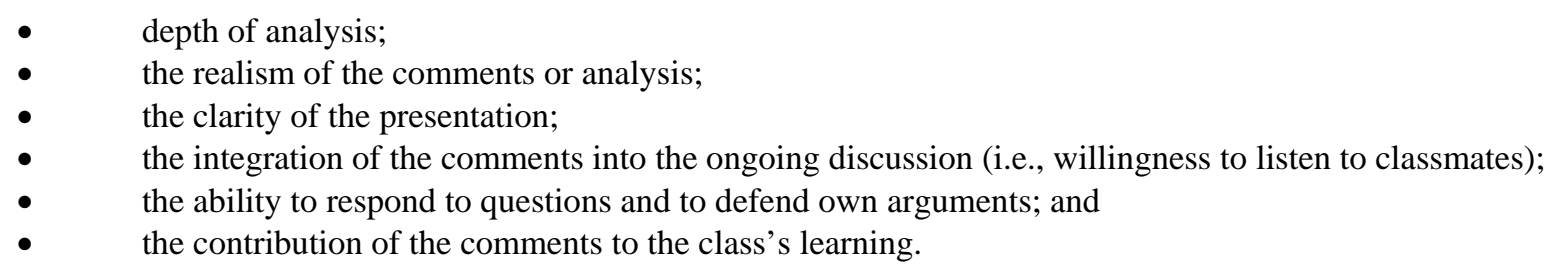


TABLE 4: MBA 8000 - COURSE CONTENT FOR FALL 2004

\begin{tabular}{|c|c|c|}
\hline Class \# & General Topics & $\begin{array}{l}\text { Preparation Material } \\
\text { (Accessible Via Www.Study.Net) }\end{array}$ \\
\hline Class 1 & $\begin{array}{l}\text { - Syllabus } \\
\text { - Management challenges in emerging industries } \\
\text { - Creating value in organizations } \\
\text { - Fastest growing, most admired etc. companies }\end{array}$ & $\begin{array}{ll}\text { - } & \text { Syllabus } \\
\text { 1) } \quad \text { Can you create more value? }\end{array}$ \\
\hline Class 2 & $\begin{array}{l}\text { - Economic forces behind value creation } \\
\text { - Industry-level forces behind value creation } \\
\text { - Competitive forces and strategy }\end{array}$ & $\begin{array}{l}\text { 2a) How competitive forces shape strategy } \\
\text { 2b) Case: Apple Computer } 2002\end{array}$ \\
\hline Class 3 & $\begin{array}{l}\text { - Resource-based view of the firm and competitive } \\
\text { advantage } \\
\text { - Resources, capabilities and competences of the firm } \\
\text { - Firm-level value chain }\end{array}$ & $\begin{array}{l}\text { 3a) The core competence of the corporation } \\
\text { 3b) Case: Southwest Airlines } 1993\end{array}$ \\
\hline Class 4 & $\begin{array}{l}\text { - Customer and market trends } \\
\text { - Competition in an emerging industry } \\
\text { - Satisfying consumer value requests }\end{array}$ & $\begin{array}{l}\text { 4a) Understand what customers value } \\
\text { 4b) Case: Land Rover North America }\end{array}$ \\
\hline Class 5 & $\begin{array}{l}\text { - Strategic IT plans } \\
\text { - Operations Management } \\
\text { - Information Systems } \\
\end{array}$ & $\begin{array}{l}\text { 5a) } \text { Getting IT right } \\
\text { 5b) } \quad \text { Case: Andina Bottling }\end{array}$ \\
\hline Class 6 & $\begin{array}{l}\text { - IPO’s as part of entrepreneurial finance } \\
\text { - Pricing of IPO’s } \\
\text { - IPO of Google } \\
\end{array}$ & $\begin{array}{l}\text { 6a) A note on the initial public offering process } \\
\text { 6b) Case: W.R. Hambrecht + Co: OpenIPO }\end{array}$ \\
\hline Class 7 & Mid Term Exam & \\
\hline Class 8 & $\begin{array}{l}\text { - Discussion of Mid Term Exam } \\
\text { - The Lexus and the Olive Tree } \\
\text { - Actual topics }\end{array}$ & \\
\hline Class 9 & $\begin{array}{l}\text { - Business Failures and their causes } \\
\text { - Bankruptcy procedures } \\
\text { - Bankruptcy and financial conditions }\end{array}$ & $\begin{array}{l}\text { 9a) The trouble I’ve seen } \\
\text { 9b) Case: Jeepers!Inc in } 2000\end{array}$ \\
\hline Class 10 & $\begin{array}{l}\text { - Leadership and Governance in mature systems } \\
\text { - Contrast US and German systems } \\
\text { - Roles of CEO and BoD }\end{array}$ & $\begin{array}{l}\text { 10a) In defense of the CEO chair } \\
\text { 10b) The board's missing link } \\
\text { 10c) Case: Banking on Germany? }\end{array}$ \\
\hline Class 11 & $\begin{array}{l}\text { - Angel Investing and Venture Capital } \\
\text { - Growth effects on financial statements } \\
\text { - Financing of growth }\end{array}$ & $\begin{array}{l}\text { 11a) How venture capital works } \\
\text { 11b) Angel Investing: Innovation within the } \\
\text { establishment } \\
\text { 11c) Case: Growing up in China: The financing } \\
\text { of BabyCare Ltd }\end{array}$ \\
\hline Class 12 & $\begin{array}{l}\text { - Mature phase of the product life cycle } \\
\text { - Innovations in mature industries } \\
\text { - Competition in mature industries }\end{array}$ & $\begin{array}{ll}\text { 12a) } & \text { Creativity is not enough } \\
\text { 12b) } & \text { The discipline of innovation } \\
\text { 12c) } & \text { Tough-minded ways to get innovative } \\
\text { 12d) } & \text { Case: The Nespresso Story } \\
\end{array}$ \\
\hline Class 13 & $\begin{array}{l}\text { - Supply chain management } \\
\text { - Ford's supply chain strategy } \\
\text { - Virtual integration: The case of Dell } \\
\end{array}$ & $\begin{array}{l}\text { 13a) The power of virtual integration } \\
\text { 13b) Case: Ford Motor Company: Supply chain } \\
\text { strategy }\end{array}$ \\
\hline Class 14 & $\begin{array}{l}\text { - Role of a Leader } \\
\text { - Effective managers }\end{array}$ & $\begin{array}{l}\text { 14a) Why should anyone be led by you? } \\
\text { 14b) What leaders really do } \\
\text { 14c) What effective general managers really do } \\
\text { 14d) Case: Charlotte Beers atOgilvy\&Mather } \\
\text { Worldwide }\end{array}$ \\
\hline \multirow[t]{2}{*}{ Class 15} & $\begin{array}{l}\text { - The Lexus and the Olive Tree } \\
\text { - Review and Synthesis } \\
\end{array}$ & \\
\hline & Final Exam & \\
\hline
\end{tabular}


Exhibit 1: Cases, Readings, and Economist/WSJ Articles for the First Two Weeks of the Class
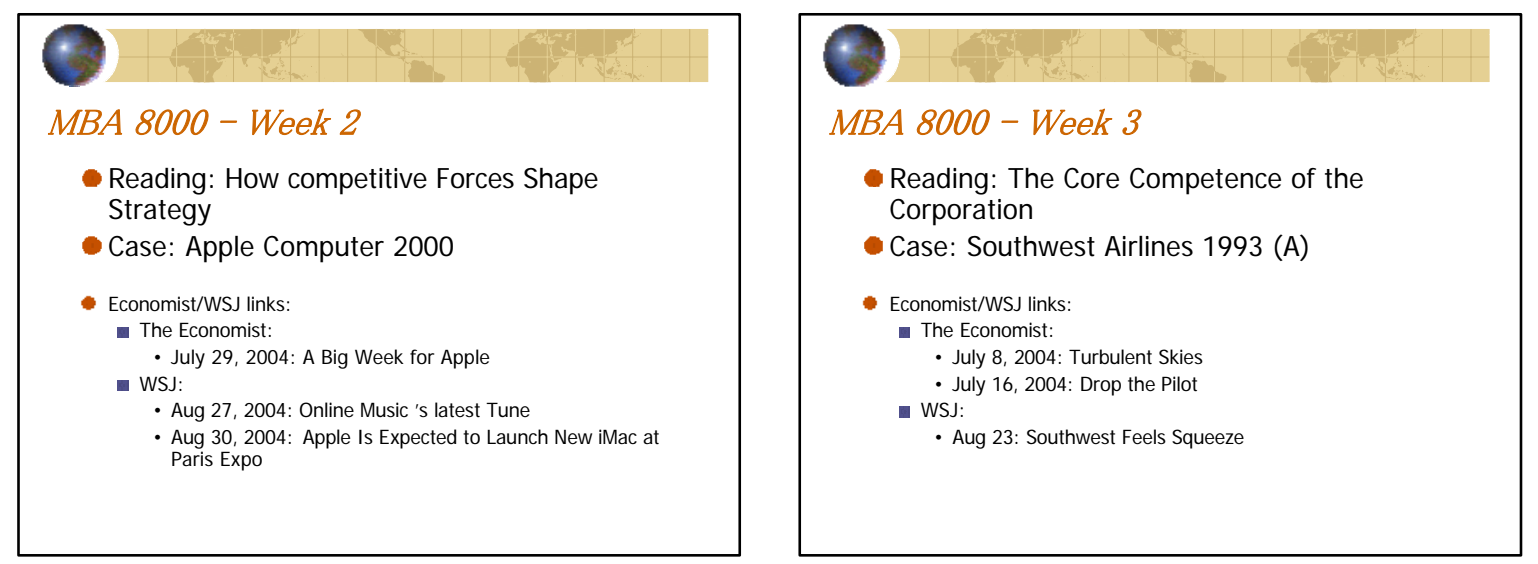

The points of the instructor-specific component were allocated at the discretion of the instructor. This component was for example a group project, presentation and/or paper, one or more quizzes, a take-home assignment, etc.

Finally, each student was required to attend at least one session of the RCB's “Atlanta Business Leaders Speaker Series." Each of these sessions featured a prominent Atlanta business executive and included an address of approximately 60 minutes, followed by 45 minutes of Q\&A, and concluding with a 45 minute networking session with refreshments provided.

MBA 8000, Managing in the Global Economy, was extremely well received by the students. The course evaluations which are done on a regular basis for all classes, showed the class as a whole at the top of all MBA prefixed courses of Fall semester 2004. This was an incredible success and was more than anybody would have reasonably expected. Also, the evaluations for the four instructors were extremely high, but this came a little bit less of a surprise because they all had a long reputation of being excellent classroom performers in their own main fields.

\section{THE SECOND AND FURTHER ROUNDS OF THE COURSE}

The same four instructors taught the course in Spring 2005 in multiple sections again. While it was clear that the fundamental underlying course matrix would not change, the team wanted to continue to improve the course. In a detailed feedback session the instructors decided to replace the content of weeks 5 and 11 . Table 5 below shows the new content and preparation material:

TABLE 5: REPLACED CONTENT AND PREPARATION MATERIAL

\begin{tabular}{|c|c|c|}
\hline $\begin{array}{c}\text { Class } \\
\#\end{array}$ & General topics & $\begin{array}{l}\text { Preparation Material } \\
\text { (accessible via www.study.net) }\end{array}$ \\
\hline $\begin{array}{c}\text { Class } \\
5\end{array}$ & $\begin{array}{l}\text { - Strategic IT plans } \\
\text { - Information Systems } \\
\text { - ERP Implementation }\end{array}$ & $\begin{array}{ll}\text { 5a) } & \text { Getting IT right } \\
\text { 5b) } & \text { Enterprise Resource Planning } \\
\text { 5c) } & \text { Case: Tektronix, Inc.: Global ERP Implementation }\end{array}$ \\
\hline $\begin{array}{c}\text { Class } \\
11\end{array}$ & $\begin{array}{l}\text { - Ethical conflicts in Global Management } \\
\text { - Stakeholder responsibility } \\
\text { - Corporate social responsibility }\end{array}$ & 11) Corporate Social Responsibility: Whether and how? \\
\hline
\end{tabular}

Exhibit 2 below shows the first ppt-slide for the redesigned weeks 5 and 11, containing the cases, readings, and also the corresponding articles from the WSJ and the Economist. 


\section{EXHIBIT 2: CASES, READINGS, AND ECONOMIST/WSJ ARTICLES FOR WEEKS 5 AND 11 OF THE CLASS}
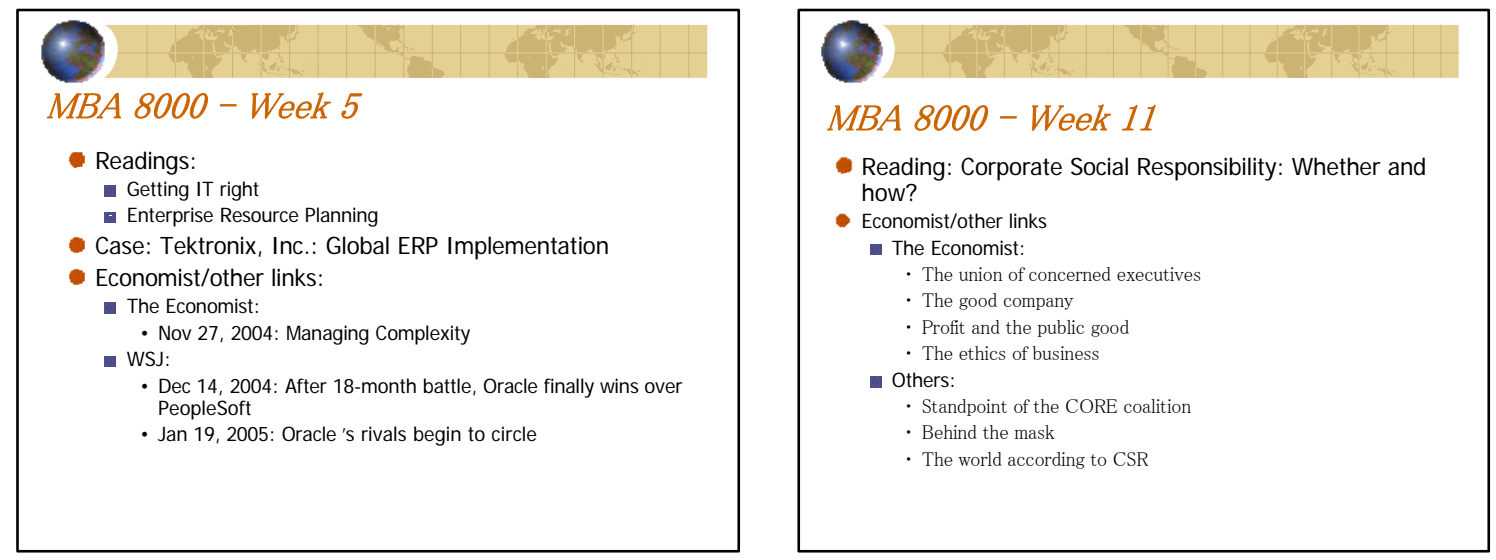

The rest of the course remained unchanged. The instructor team continued to hold weekly meeting during which the contents of the past and next class were discussed. Not surprisingly, MBA 8000 was again very successfully delivered in Spring 2005 and continued to be a huge success. The students seemed to like the course's framework and content very much. The word had spread out that this would be an excellent class and student's expectations had therefore become pretty high.

In Summer 2005 the class was taught again, this time in two sections. One section was a 3-week class that met every day for three subsequent weeks (so-called Maymester class). The other section was delivered in 8 weeks (this is the duration of the Summer semester, whereas the regular Fall and Spring semesters consist of15 weeks), which meant that the class met twice a week. No changes were made to the content compared to the Spring class. And once again the student feedbacks were excellent.

The only thing that turned out to be more difficult than expected was the attempt to extend the team of instructors. Ideally, so thought the instructors team as well as the Associate Dean for Masters Programs, there should be a certain rotation in the course coordination as well as in the instructor team. However, this would require 7-8 faculty members who would be willing and able to be part of the MBA 8000 team and therefore take responsibility for its continuing success. Several colleagues, who were asked if they wanted to join, expressed some reservations. Either they were hesitant because of the perceived burden of work for a first-time preparation of the class, or they were reluctant to join a team that had proven to be very successful. Occasionally they also mentioned the fact that there would be no adequate compensation for the additional efforts and risks.

\section{SUMMARY: THE KEY FACTORS FOR SUCCESS}

Without any doubt, MBA 8000 - Managing in the Global Economy - has become a landmark in Georgia State University's MBA program, and what seemed at first to be an impossible thing turned out to be a highly successful innovation.

Why was it possible to develop, implement, and deliver this type of class? In our opinion there were at least seven key factors that are partially responsible for the success:

- $\quad$ A strong Associate Dean for Master's Programs who insisted on a thorough analysis of structure and content of the existing MBA program and on developing a modern, integrated curriculum;

- A broad involvement of many different departments of the business school in the MBASC, so that the responsibility of the program development was shared and nobody felt left out; 
- $\quad$ A step-by-step approach that allowed to redesign the MBA program top-down, i.e. by first setting the general parameters of the program, then the general structure of the different classes, and then the detailed content of particular courses;

- $\quad$ Regularly held MBASC meetings created an environment where as much communication as possible was strongly encouraged;

- $\quad$ An efficient course coordination for MBA 8000 with weekly meetings and standardized procedures helped to "maintain the course of the ship"

- $\quad$ An instructor team that consisted of dedicated, experienced classroom managers with a genuine interest in business and a willingness to approach new territory;

- $\quad$ As usual, a unified, strong desire “to make it happen”!

Italy can of course be discovered in different ways. Our approach starts with a four-week visit, followed then by a one-year stay. And while the Espresso may be a little bit too strong at times and the day-to-day life occasionally too hectic or even chaotic, in the end we hopefully agree with the Italians: Il paese e bello (the country is beautiful)! 
NOTES 